Revista de la red interuniversitaria de estudios sobre las literaturas rioplatenses contemporáneas en Francia

$14 \mid 2016$

Levrero

\title{
Para abrir el libro
}

Jean-Luc Nancy

Traductor: Martín Arias

\section{CpenEdition}

\section{Journals}

Edición electrónica

URL: http://journals.openedition.org/lirico/2298

DOI: $10.4000 /$ lirico.2298

ISSN: 2262-8339

Editor

Réseau interuniversitaire d'étude des littératures contemporaines du Río de la Plata

Referencia electrónica

Jean-Luc Nancy, « Para abrir el libro », Cuadernos LIRICO [En línea], 14 | 2016, Puesto en línea el 07 junio 2016, consultado el 20 abril 2019. URL : http://journals.openedition.org/lirico/2298 ; DOI : 10.4000/lirico.2298

Este documento fue generado automáticamente el 20 abril 2019.

\section{cc) (i) $\Theta$}

Cuadernos LIRICO está distribuido bajo una Licencia Creative Commons Atribución-NoComercial-

SinDerivar 4.0 Internacional. 


\title{
Para abrir el libro
}

\author{
Jean-Luc Nancy \\ Tradución : Martín Arias
}

\section{NOTA DEL EDITOR}

Cuadernos LIRICO agradece al autor y a los editores la cesión de los derechos para publicar el presente texto. Procedencia : « Pour ouvrir le livre ». Demande. Littérature et philosophie (textos reunidos con la colaboración de Ginette Michaud). París, Galilée, 2015, pp. 97-102. Las notas del traductor irán entre corchetes.

\section{1}

Cuando el libro está cerrado, hay tres posibilidades.

2 La primera consiste en no abrir el libro, ya literalmente, ya al menos en el sentido de que abrirlo y leerlo suponen repetir el texto ya conocido, aprendido en la infancia y guardado, como se dice, en el corazón ${ }^{1}$, es decir, según una intimidad que lo preserva intacto en su recitación. En ella, puede decirse que el libro permanece indefinidamente abierto, y en cierto modo clausurado en su despliegue.

3 La segunda posibilidad es deslizar un alfiler en el espesor de las páginas, al azar, y practicar las suertes virgilianas, que consistían en encontrar un oráculo en la primera palabra hallada. Se las practicaba con la Eneida, que era considerada como un poema inspirado por los dioses. A una forma generalizada de este ejercicio se la ha denominado "bibliomancia" y, como era de esperar, ta biblia fueron su terreno predilecto. Semejante práctica equivale a no abrir el libro : se le echa una ojeada, se le toma una instantánea.

4 La tercera equivale simplemente a abrir el libro y mantenerlo abierto pasando las páginas. Esta apertura es un movimiento. Este movimiento no es sólo la sucesión de las páginas que se levantan y se repliegan una tras otra -animación que las nuevas máquinas de leer informáticas se afanan por restituir en una ductilidad de imágenes-. 
5 Practicamos las tres posibilidades simultáneamente, alternativamente, sin saberlo siempre. Leemos salmodiando suavemente el texto en algún lado al fondo de la camera oscura que lo filma. Somos captados al azar por una palabra, un giro de la lengua en el que recogemos una especie de augurio que no se refiere directamente a nuestra vida, sino al sentimiento de un posible e inédito incremento de sentido.

6 Y seguimos pasando las páginas, manteniendo el libro abierto, al menos mientras deseamos proseguir. Y lo deseamos si hemos entrado en el libro. Es así como lo expresamos : decimos "no pude entrar", o bien "una vez que entrás, ya no parás". Hay entonces un estado, o más bien un vínculo en que el libro no sólo está abierto ante nosotros, sino que nosotros estamos en él, avanzamos a su paso, nos reconocemos en él y cuando, después de haber tenido que interrumpir la lectura, la retomamos, todo un mundo vuelve a su lugar. Ese mundo está a nuestro alrededor, está en nosotros, ya no es posible establecer la diferencia : ahí estamos, se trata de un lugar, esto es, ahí tienen lugar eventos, ahí se prosiguen o se contraen periodos de tiempo, se extienden o se encierran espacios. Vemos a las personas, los paisajes. Compartimos impresiones, esperas, sorpresas. (De ahí la decepción casi inevitable que produce toda transposición de la novela al cine : puede ser más o menos hábil, sutil y lograda ; lo que seguirá siendo difícil de superar es la imposición de imágenes ahí donde habíamos creado nuestro propio mundo de visiones evanescentes.)

7 No es sólo el caso del relato y la ficción. Un texto de pensamiento -lo que no es lo mismo que un documento de información- viene siempre acompañado de un ritmo, una cadencia, de inflexiones y evocaciones de imágenes o afectos.

8 Leamos por ejemplo lo siguiente en Merleau-Ponty: "Únicamente el motivo central de una filosofía, una vez comprendido, da a los textos del filósofo el valor de signos adecuados. Se da, pues, una prosecución del pensamiento del otro a través de la palabra, una reflexión en el otro, un poder de pensar según el otro, que enriquece nuestros propios pensamientos"2.

9 De esta frase no sólo comprendemos el sentido, sino que ella se nos comunica de modo sensible, a través de palabras como "prosecución" o "reflexión en", a través de las bastardillas de "según", etc. Se podría decir que la frase hace lo que dice... Que toda palabra es performativa es una indicación que se encuentra al menos en Derrida, pero también en la experiencia y, de modo singular, en la de la literatura.

\section{2}

10 Pues ésta no lleva su nombre por nada: ella pone la letra en acto. La letra es la articulación, el corazón de la palabra y del lenguaje. Es decir, no solamente las dos articulaciones -semántica y fonética- propias del lenguaje, sino la pronunciación, la emisión, la modulación, el tono, el estilo y eso que ha llegado a llamarse escritura.

11 Merleau-Ponty continúa en el mismo lugar: "Necesario es que, aquí, el sentido de los vocablos venga inducido por las palabras mismas, o más exactamente, que su significación conceptual se extraiga de una significación gestual inmanente en la palabra"3.

12 La literatura es gesto, en la misma medida en que es palabra. $Y$ es en esencia oral, como le gustaba afirmar a Lacoue-Labarthe ${ }^{4}$. Esto significa a la vez que se la dirige, se la envía, y que sólo encuentra o da su sentido en su envío (no nos atrevemos a decir en su envión hacia lo alto, y sin embargo...). La apertura del libro es el telón alzado sobre el escenario 
de esos gestos de envío. Allí son actuadas todas las posibilidades, posturas, cadencias, invenciones de eso que reúne su energía inicial en esta fórmula de Didier Cahen : "yo hablo por el otro"s. A la vista del otro, al otro, en su lugar, en su nombre.

13 Y el otro, claro, -sí : aquel cuya palabra hemos escuchado de modo claro- es también "yo mismo", que tiene poco o nada que ver con este yo que habla. $Y$ es, tanto en mí mismo como en el otro sí mismo, la apertura hacia un para el otro: otra parte, un afuera que esencialmente no debe tener forma ni función de meta o de destino, de cumplimiento de trayecto ni de conclusión de operación. Al contrario, es de esperar que salgamos de todos esos registros, que los olvidemos y dejemos que los substituya una especie de deriva ocupada de sí misma : ésa a la que cede el lector cuando avanza en el libro.

14 Es entonces cuando está abierto. Está abierto a lo que contiene y entrega : un sentido que se despliega (se produce, se traza) por sí mismo y para ningún otro fin. Que se vea en ello esparcimiento, diversión, nada tiene de ofensivo: se trata en efecto de dejarse divertir, desviar de las necesidades de intención y producción, y de dejar advenir un gesto que señale hacia el deslumbramiento en el cual comprendemos, por un instante, que el mundo aparece cuando nosotros lo hacemos aparecer. Y "nosotros" es cada vez "yo", un solo para todos, cuando menos para muchos.

15 "Comprendemos": es decir demasiado, es decir mal. Más bien somos comprendidos, prendidos, capturados por la apertura del libro hacia la cual hemos sido arrastrados (o no : hay libros que se mantienen cerrados para mí, u otros que vuelven a cerrarse ; nunca se agotará la exploración de esa delicada cuestión del gusto, las inclinaciones, las pulsaciones, tanto en ésta como en toda materia sensible, estésica...). Y sin embargo hemos comprendido, hemos quedado prendidos de un pensamiento. Que es siempre pensamiento a la vez de un relato, de una figura, de un tono, de una lengua y pensamiento de esto : que todo eso nos es dicho, contado, ahí adelante, en el libro, a distancia, en una ficción o en un discurso -no importa : en un elemento que se desprende del mundo y flota ahí adelante-.

\section{3}

16 Que flota incierto, lábil, inconsistente, irreal -literatura: todo el resto-. El resto de lo serio, de lo construido, de lo cierto, de lo comprobado. Pero ese resto es también lo que precede a toda ocupación seria, del tipo la-vida-la-muerte, el-sufrimiento-el placer, lalabor-el-descanso. Precede a todo ello porque el habla es más antigua y porque, en el habla, aún más antiguo es el proferir : el llevar algo delante de sí, presentarlo, declararlo.

Declarar -como se declara una mercancía, un amor, una sociedad, la apertura de una sesión- significa (calo, clamo) hacer resonar. Lo real no es si no resuena en lo irreal. Ahí está aquello que nos precede y sin lo cual no seríamos los animales parlantes, aquello sin lo cual los animales mismos no serían los que al mugir, gorjear o ladrar hacen ya retumbar el mundo.

Es por ello que la literatura es oral: se abre en un estruendo jamás comenzado, jamás terminado, en una glosolalia de la presencia sin la cual todo estaría puramente ausente.

Pero es por ello que es escrita : el estruendo debe volver, debe repetirse, hacerse eco para escucharse y reanudarse. La literatura es escrita en su oralidad misma: se la recita, se la aprende de memoria, es fórmula y cadencia. Cuando llega, la escritura es sólo esa antecedencia de la resonancia que se expone como tal. 
$20 \mathrm{Y}$ es precisamente por eso que entre todos los oficios, uno solo ignora la jerarquía : el escriba es su propio jefe, afirma el egipcio Jety (cuya astuta broma comporta su muy serio reverso : es justamente entre las manos del escriba donde todas las otras actividades se encuentran consignadas, contadas, declaradas).

21 La literatura: la declaración que no tiene otra cuenta para rendir que su propia inscripción, su articulación, su circulación, su recitación, su lectura. Lo escrito no alcanza en verdad el mundo de las cosas : prueba de ello es que el libro sólo vale por su apertura y por su resonancia cuando vuelve a cerrarse, siempre de modo provisorio. El libro sólo es objeto notable y bibliofílico en la medida en que es materia sensiblemente impalpable. Es liber, delgada película extraída entre el cortex y la materia ; tiene la consistencia ínfima de una forma.

22 La hoja -piel, papiro, papel, pantalla- es el lugar de lo que Duchamp llama lo infradelgado, uno de cuyos ejemplos se halla en "El hueco del papel entre el anverso y el reverso de una fina hoja...". Y apoyándonos en Hesiquio, podemos suponer que la literatura debe su nombre a una transcripción de la palabra griega diphtera, la cual designa la piel curtida, el cuero afinado con que se hará el pergamino. Se trata siempre de piel, de película, de aquello por lo cual las cosas vienen a declararse a la superficie y las unas a las otras.

23 Abierto el libro, todas sus hojas resuenan entre ellas y todos los libros, cada uno a su vez, se abren los unos a los otros, los unos en y por los otros -resto elocuente de este mundo fortuito-. (2013)

\section{NOTAS}

1. [En el original se enfatiza el sentido literal de una locución en la cual figura la palabra "corazón" (par cœur) y cuya versión castellana es "de memoria". ]

2. Maurice Merleau-Ponty. Phénoménologie de la perception. CEuvres. París : Gallimard, 2010, p. 865. [Versión castellana : Fenomenología de la percepción. Barcelona : Ediciones Península, 1994, p. 196 (trad. de Jem Cabanes).]

3. Cf. Philippe Lacoue-Labarthe, Phrase. París : C. Bourgois, 2000, p. 173. [Traducción ligeramente modificada].

4. Ibíd.

5. Didier Cahen. À livre ouvert. París : Hermann, 2013. 